\title{
State and COVID-19 Response in the Asian Tiger Economies
}

\section{Hong Kong, Taiwan and Singapore}

\author{
Habibul Haque Khondker | ORCID: 0000-0002-5545-7599 \\ Department of Social Sciences, Zayed University, Khalifa City, \\ Abu Dhabi, UAE \\ habibul.khondker@zu.ac.ae
}

\begin{abstract}
By comparing the response to the CoviD-19 pandemic in the Tiger economies, Hong Kong, Taiwan, and Singapore, this article examines the advantages and limitations of the statist command and control approaches to crisis management. Local, regional, and global politics as well as global political economy impinge and influence the state response. The article argues that a combination of factors - the institutional memory, overall state capacity and efficacy rooted in the preexisting institutional nexus, performance legitimacy, trust, reliance on scientific rationality, and integration with global scientific networks - stood in good stead in dealing with the crisis. Yet, as the crisis rolled on, some of the stellar performers showed considerable gaps in planning and politics trumped sensible policies. Despite the commonality, the article shows that there were important differences in the responses of the three Tiger economies, especially in rolling out the vaccines, which can be explained not only by the state capacity but also the larger global politico-economic contexts. The article argues that the state capacity is affected by the global dynamics, the specificity of geopolitical and historical contexts, which must be factored in in explaining successes and failures of state responses.
\end{abstract}

\section{Keywords}

COVID-19 response - statist approach - governance - political economy geopolitics - globalization 
This article compares the response to COVID-19 crisis in the three Tiger economies: Hong Kong, Taiwan, and Singapore. Initially, the Tiger economies enjoyed relative success in containing the COVID-19 pandemic and received accolades from around the world. However, as the pandemic entered the second year, things changed; countries such as UK and the US which were laggard in crisis response initially showed great success in vaccine campaigns, and countries once models of success faltered in vaccination of their people. Other than New Zealand and a few other small countries, most countries around the world went through the rollercoaster effects of highs and lows. The virus - SARs$\mathrm{CoV}-2$ - has been more elusive than the other pathogens that humanity had to deal with in the recent past. In terms of response, the article argues that a combination of factors: the institutional memory, overall state capacity and efficacy rooted in the preexisting institutional nexus, performance legitimacy, trust, reliance on scientific rationality, and integration with global scientific networks help explain the role of the state in dealing with a national crisis. Yet, the global factors which include a raft of factors including vaccine economics, or distribution politics, or access to vaccine as in the case of Taiwan, hamstring state action. The Tiger economies have been well-integated into the global economic system. Of the three, the Singapore state enjoyed more autonomy from the constraints of geopolitics thus was one of the first countries to place an order with the Pfizer for the Pfizer-Biontech vaccine. In the case of Taiwan, there was hindrence from China that offered vaccine made and used in the People Republic of China (PRC) but embargoed procurement of vaccine made in the United States. Hong Kong, technically, a Special Administrative Zone (SAR) off China was able to exercise relatively more autonomy in procuring sufficient amount of vaccine from the international market. The circumstances in Taiwan and Hong Kong are conditioned by the historical legacy of geopolitics as China (the People's Republic of China) claims Taiwan to be a province of the mainland ignoring Taiwan's claim of its de facto sovereign status. The ambiguity in the status of Taiwan has had consequences for its pandemic response.

This article explores how lessons of good governance - especially, transparency meaning an open approach to governance with great deal of information made available and keeping the system as free of corruption as possible - aids in executing an effective response. It is transparency along with the other features of good governance that helped fuel rapid economic development in the Tiger economies where an active and relatively autonomous state built institutions, ensured provision of a strong health care among other public goods, and acted proactively. Despite commonality, there were important differences in the responses of the three Tiger economies to the pandemic, especially in 
rolling out the vaccines, which can be explained not only by the state capacity but also the larger global geopolitical and politico-economic contexts. The article argues that in addition to good governance manifested in - integrity, transparency, and accountability - as a requirement for better handling of the crisis, both the global dynamics and the specificity of geopolitical and historical contexts weigh in in explaining successes, lapses, and failures.

The Covid-19 pandemic has already claimed over 5.2 million human lives and inffected over 245 million people worldwide as of October 28, 2021 according to Reuters (Rueters, 2021) and despite the appearance of vaccines and the successful vaccination in several countries, the end of the pandemic is not in sight globally and as of late October 2021 the coronavirus is rising in 56 countries (Reuters, 2021) and its fallouts are likely to affect the world economy in the years to come. Scientists are also concerned over the long-term effects on the health of the survivors with likely impact on labor force supply (The Economist, 2021a). The COVID-19 pandemic has put the states of the world and the very process of globalization to a test.

Recent studies address the impact of the crisis on politics and society, (Delanty, 2021) or focus on issues of governance in a comparative vein (Jasanoff, et al., 2021; Nederveen Pieterse, et al., 2021). As we look at the pandemic and the response it has generated globally by individual countries, the responses of some of the Asian economies are noticeable for their quick execution and smart engagement that has resulted in limiting the death tolls. These societies have shown resilience and determination guided by leadership who could harness the institutions of the society through effective and timely policy interventions. These three countries were able to deal with the contingencies and challenges that the larger political-economic forces presented. In the East Asian cases, the public health-care system led the charge. "The least neoliberal countries in the world, many in the global south, have so far come through the pandemic in better shape: China, South Korea, and Taiwan" (Fouskas and Gokay, 2020). Here by least neoliberal countries we mean countries that have institutionalized the centrality of the state in both running the affairs of the state as well as in crisis response. In the Tiger economies as the states have been major drivers of socio-economic transformations, in fighting the coronavirus-caused pandemic too, relatively autonomous states were at the forefront of crisis response.

The Asian Tiger economies from the very start opted for the hammer rather than a dance approach unabashedly. ${ }^{1}$ The hammer approach alludes to strong

1 A group of economists at Toulouse School of Economics in France in mid-May 2020 introduced these useful metaphors in recommending a nuanced response to the pandemic crisis addressing both the economic and health policy objectives simultaneously. 
measures in the initial stage to contain the virus through strict, no-nonsense lockdown. The dance approach implies gradual opening of the economy aided by contract tracing and other precautionary measures. In a joint study produced by Harvard and Cornell, a number of writers have examined the CoviD-19 response across eighteen countries. In terms of response and the effectiveness of responses, countries have been classified as Control, Consensus, and Chaos countries (Jasanoff, et al., 2021). China is a control country. Germany approximates a consensus country. Brazil, Italy, US and India are chaos countries. The Tiger Economies approximate the control countries, yet they employ a good deal of consensus approach. In the Tiger economies the initial hammer approach yielded very good results in containment but as economies began to open and as the governments began to adopt a dance approach, both the case loads and the fatalities increased.

After the second wave, as coronavirus pandemic crisis entered the second year, the picture changed. Tiger economies that once looked unassailable were faced with challenges of new waves of infections and deaths.

Hong Kong, Taiwan, and Singapore executed a rapid response on almost warfooting. All three governments launched measures before the World Health Organization formally declared CoviD-19 as a Public Health Emergency of International concern (PHEIC) on February 12, 2020 and as the pandemic on March 11, $202 \mathrm{O}$.

TABLE 1 COVID-19 in Hong Kong, Taiwan and Singapore in December 11, 2020 and in October 28, 2021

\begin{tabular}{lll}
\hline Country & $\begin{array}{l}\text { Population } \\
\text { (million) }\end{array}$ & Total cases $\quad$ Total Deaths $\quad$ Deaths per million
\end{tabular}

\begin{tabular}{|c|c|c|c|c|c|c|c|}
\hline & & $\begin{array}{l}\text { December } \\
11,2020\end{array}$ & $\begin{array}{l}\text { October } \\
28,2021\end{array}$ & $\begin{array}{l}\text { December } \\
11,2020\end{array}$ & $\begin{array}{l}\text { October } \\
28,2021\end{array}$ & $\begin{array}{l}\text { December } \\
11,2020\end{array}$ & $\begin{array}{l}\text { October } \\
28,2021\end{array}$ \\
\hline Hong Kong & $7 \cdot 5$ & 7,292 & 12,338 & 114 & 213 & 15 & 28 \\
\hline Taiwan & 23.8 & 724 & 16,334 & 7 & 847 & 0.3 & 35 \\
\hline Singapore & 5.8 & 58,297 & 184,419 & 29 & 349 & 5 & 59 \\
\hline
\end{tabular}

SOURCE: WORLDOMETER, HTTPS://WWW.WORLDOMETERS.INFO/CORONAVIRUS/ \#COUNTRIES (ACCESSED ON DECEMBER 11, 2020 AND ON OCTOBER 28, 2021). 
As early as December 31, 2020, Taiwan issued travel alerts to China and border control, where direct flights arriving from Wuhan were all screened onboard. Just before the holidays, the Central Epidemic Command Center (CECC) was activated for critical roles of oversight, coordination, and communication. On January 21 2020, Taiwan reported its first imported coviD-19 case returning from Wuhan (Hsieh, V. 2020:884). Hong Kong Secretary of Food and Health Professor Sophia Chan appealed to the people who had visited Wuhan to report to doctors if they felt unwell. Not only were sensible policies adopted, they were implemented rapidly.

Singapore, with 400 weekly flights from China used to receive a large volume of tourists from mainland China. As such it was one of the first countries to report imported COVID-19 cases and had the highest number of cases outside mainland China for a time in February 2020. The government responded with a series of broad public health measures and managed to contain this first wave of infection quite expeditiously (Chen, J.I.P. et al., 2020).

Hong Kong reported its first confirmed COVID-19 case on January 23, 2020. However, from early January, Hong Kong authorities enhanced surveillance as the doctors were asked to report to the Centre for Health Protection of nay patients with fever and acute respiratory or pneumonia symptoms who had visited Wuhan within fourteen days before the onset of the illness. Railway stations linking China also came under enhanced. surveillance. Forty-four Wuhan related cases were detected by January 3, 2020 (Hong Kong Government, 2020). By January 4, a three-tier response strategy was adopted. However, as early as January 3, Hong Kong deployed measures to check body-temperature at the railway station for incoming passengers from China and Hong Kong International Airport for passengers coming from Wuhan, this was more than two weeks before China officially declared its first coronavirus related death on January 21. By the first week of January Hong Kong was treating patients with influenza symptoms who visited Wuhan. The Hong Kong chief executive Carrie Lam even visited the borders to see the temperature checkpoints.

Hong Kong, Singapore, and Taiwan suffered from the first wave of coronavirus SARS- 1 in 2003. They could use their institutional knowledge and experience and deploy it more effectively than other states. The 2003 SARS or severe acute respiratory syndrome, infected over 8,00o and killed 774, including 299 in Hong Kong. The result of SARS was devastating for the Asian cities Singapore and Hong Kong included. The Asian Tigers were able to leverage on the hardwon lessons to combat the new coronavirus, Covid-19. 
Hong Kong, Taiwan, and Singapore experienced pandemics such as SARS and MERS in 1993 and 2001 respectively. The experience of SARS and MERS was embedded in the continued political systems and played a key role. The experience was utilized by a highly rational bureaucracy. Their responses have been swift, well-communicated that minimized the damage, and implemented effective policy measures. One of the reasons these three countries were able to absorb institutional memories was partly because of the continuity of the regimes undergirding political stability in these countries.

During the SARS epidemic in 2003, selective border controls were introduced and temperature testing at the airport was installed. Such knowledge stood in good stead at the onset of the CoviD-19 pandemic. Hong Kong, Taiwan, and Singapore were quick to impose border control with China, disconnecting flights with Wuhan, the epicenter of the virus leading to shut down of the travel. The three countries also used effective contract tracing. Taiwan not only closed its borders it also blocked local coronavirus transmission through a combination of rigorous contract-tracing, a mandatory 14-day quarantine period for every person who enters from abroad and near-universal mask-wearing.

Following the 2003 SARS experience, Singapore developed a colour-coded "Disease Outbreak Response System Condition" (DORSCON) that incorporated progressive degrees of border controls, community-based measures, infection control in hospitals, and other containment/mitigation measures. This raised awareness nation-wide, and facilitated a coordinated response, across sectors, to varying stages of infectious disease spread. On 7 February, with the discovery of several cases of COVID-19 with no links to previous cases or travel history to China, Singapore raised the Dorscon level to orange (Chen, J.I.P. et al., 2020:562).

Taiwan also benefitted from its experience of dealing with the 2003 outbreak of Severe Acute Respiratory Syndrome (SARs) that killed 8oo people across the world. Taiwan's 2020 pandemic response was largely mapped out through extensive planning as a result of the SARs pandemic in 2003 and was developed in such a way that it could be adapted to new pathogens. Taiwanese learnt the lessons of protective behavior from the 2003 SARS experience. A study comparing the wearing of facemasks in Taiwan revealed that the proportion of participants wearing facemasks significantly increased from $66.6 \%$ during the 2003 SARS/2009 HiN1 pandemic to $99.2 \%$ and $80.9 \%$ in indoor and outdoor environments, respectively, during CoviD-19 (Yen, M.H., et al., 2021).

Following SARS in 2003, Taiwan established a central command center for epidemics. In 2004, the year after the SARS outbreak, the Taiwan government established the National Health Command Center (NHCC). The NHCC is part 
of a disaster management center that focuses on large-outbreak response and acts as the operational command point for direct communications among central, regional, and local authorities. Of Taiwan's 23.8 million citizens 850 ooo reside in and 404000 work in China. In 2019, 2.71 million visitors from the mainland traveled to Taiwan. This made Taiwan was on constant alert and ready to act on epidemics arising from China ever since the severe acute respiratory syndrome (SARS) epidemic in 2003 (Wang, Ng, and Brook, 2020). NHCC quickly got into action.

By January 20, it was coordinating the government's response to the coronavirus. It quickly compiled a list of 124 "action items," including border controls, school and work policies, public communication plans, and resource assessments of hospitals. When the Covid-19 pandemic struck early this year, Taiwan quickly rolled out a nationwide facemask distribution system with a "mask map" that showed where they were available. But it wasn't a smooth launch. Complaints poured in from people who had to wait in long lines and were often disappointed when vendors ran out of stock. A team headed by Taiwan's Digital Minister Audrey Tang soon stepped in with a set of solutions based on inclusion principles that brought in input from the community. The effort resulted in constantly updated map apps that de-list locations when they run low on masks. It also brought in a numbering system that eliminates long waits and guarantees that citizens can efficiently obtain masks. More than 10 million people have used the apps. The Minister attributed the success to the cooperation of the masses.

Based on the SARS experience of 2003, Singapore government mounted a coordinated response and set up a multi-ministry task force on 22 January to oversee the national response to CoviD-19. It comprised members across multiple ministries, including health, trade, communications, manpower, and transport (Chen, J.I.P., et al., 2020). The Multi-Ministry Taskforce (Ммт) was jointly chaired by the Minister for Health and the Minister for National Development with eight other ministries and the Deputy Prime Minister as the advisor (Abu Baker, 2020).

\section{$4 \quad$ Lack of Institutional Memory and Vaccine Crisis}

While institutional memories stood in good stead in fighting and containing the pandemic, but when it came to vaccination, such institutional memories were not of much help for two important reasons. First, SARS-1 of 2003 ended before an effective vaccine was discovered and second, the scale of the problem during the Covid-19 pandemic was very high prompting a huge gap 
between supply and demand for vaccines globally. As the rich countries of the North were sitting on a stockpile of vaccines, poorer countries were languishing with vaccine shortage. Yet, the inadequacy of vaccine in countries like Taiwan and to some extent Singapore were baffling. Especially, considering the fact that Singapore was one of the countries that booked vaccinaes early to enable delivery by December $202 \mathrm{O}$.

The difference is pronounced in vaccination of the three countries. Singapore had more than one third of the resident population vaccinated by late May 2021. Since last December, when Singapore rolled out its Covid-19 vaccination programme in staggered phases, approximately 2.2 million doses of Covid-19 vaccines have been administered, with just over one-third of the population receiving at least one dose. Singapore is administering Pfizer and Moderna vaccines (Kalimuddin, Bertoletti and Ooi, 2021). Hong Kong had less than $20 \%$ $(17 \%)$ vaccinated and many people in Hong Kong were reluctant to take the jab initiating the government to mount a lottery to entice the jab-skeptics.

Of nearly 4 million jabs from Chinese producer Sinovac and Germany's BioNTech that reached Hong Kong since February, 20212 million of them are still languishing in storage amid a sluggish inoculation campaign. By May 2021, three months into the vaccination drive, only about 1.28 million people, or 17 per cent of residents, have taken their first dose. Around 921,50o have received their second shot. Hong Kong government was not showing a lack of preparedness. The city has purchased 7.5 million shots of Covid-19 vaccines each from BioNTech and Sinovac, enough to cover the entire population of 7.5 million people. The cost has never been disclosed. The problem was at the receiving end. Vaccination was launched on February 22, 2021 in Hong Kong. Health authorities have administered about 1.25 million of nearly 2 million BioNTech doses and 953,300 shots of more than 2 million Sinovac ones. (Ting and Chan, 2021)

Taiwan, having had an initial stellar performance in combatting the virus was caught off-guard by a toxic cocktail of complacency, national politics, and international geopolitics with less than $1 \%$ vaccinated as of late May 2021 at a time when a second wave of deadly virus raised the infection level and death toll to new heights. Since the onset of the pandemic in January 2020 until the end of 2020, Taiwan had a death toll of just 7 and until May 21, only 15 with lite over 2000 infections. However, things changed swiftly. On May 27, 2021 Taiwan recorded 13 death, the highest single day since the pandemic began (Hsiao, 2021). Taiwan announced that it expects 2 million doses of vaccine by the end of June and 10 million doses by August 2021 (Lee, 2021). For Taiwan's 23.8 million people, it is still quite inadequate.

On May 28, Taiwan's health minister Chen, who heads the Central Epidemic Command Centre, announced that local authorities will be allowed to import 
of vaccine under strict safety condition changing the policy of procurement only by the central command. On the same day, Taiwan reported a further 557 new cases and yet another record of 19 deaths. Coincidentally, an opinion poll published by the Taipei-based China Times on May 2, 2021 indicated overwhelming public support - 97.7 per cent of 11,665 respondents - for allowing local authorities to place their own orders (Chung, 2021).

Taiwan has signed deals to buy 10 million shots of the AstraZeneca vaccine, 5 million doses of the Moderna vaccine and more than 4.7 million doses via the Covax Facility. Locally developed vaccines are also expected to be available in July. According to Taiwan's health minister, 10 million doses of vaccines would be available by the end of August and the island should have enough vaccines to inoculate 6o per cent of its population by October. Taiwan received 150,000 doses of the Moderna vaccines on May 28. Japan is also considering government supply a portion of Japan's AstraZeneca vaccine stock to Taiwan to help it tackle a surge in infections (Lin, 2021). On May 30, the Central Epidemic Command Center (CECC) stated that domestic manufacturing of vaccine is an established national policy for fighting against COVID-19 as the disease is likely to become like flu in the future; therefore, the government must secure COVID-19 vaccines as strategic supplies. Taiwan adopts the approach of prepurchasing to secure the vaccine doses it has bought at this stage, including 20 million doses from overseas and 10 million doses of domestically manufactured vaccines (CDC, 2021).

In Taiwan local institutions such as Sun Yat-sen school was in talks with cultural organizations in mainland China to received donation of vaccines that included both Chinese made vaccine and BioNTech vaccine, 5 million each (Chan, 2021). As local authorities from three regions sought to import vaccine from mainland China, the central authority in Taipei turned down initiatives made by the local governments. The politics trumped pandemic response. The central command, CECC, that was the linchpin in the success of pandemic response now stood in the way of vaccination.

To offset supply challenges, the Singapore Government planned to stretch out the interval between doses to six to eight weeks, to ensure nearly everyone - or 4.7 million people - gets at least one shot by early August 2021 (Teo, 2021).

Aside from or in addition to democratic legitimacy, performance legitimacy is a major plank in the legitimacy of the political systems in the Asian Tiger economies. Performance of the government in both formulation and the effective 
implementation of the policies are almost given which made it imperative that the governments have to perform better and demonstrably better than other countries to retain and earn the legitimacy by their sheer efficiency.

Performance legitimacy requires availability of appropriate institutional structures and responses in a coordinated fashion. The differences were whether the approach was top down as in Singapore or bottom up as in Hong Kong or a combination of the two as in Taiwan.

When the virus began crossing China's borders in January, Singapore appeared fated for a large-scale outbreak. The tiny city-state was the third country to report cases of COVID-19, and by mid-February, had recorded over 8 o infections, the highest outside the Chinese mainland. Singapore's rigorous testing and aggressive contract tracing resulted in the detection of an increased number of cases. Singapore's effective coronavirus response is a result of transparency, comprehensive testing, and quick quarantining and isolation of suspected cases. Singapore's Multi-Ministerial Taskforce was transparent in communication as it hosted daily media briefings and reported the cases honestly with Ministry of Communication and Information aiding in presenting the information in a differentiated manner so as to reach various target groups. They also used multi-media as well as various means including deployment of artists from Bangladesh and West Bengal to reach target audiences effectively. Transpareny built trust and trust assisted in crisis-response (Low, 2020). Singapore has a track record of a top-down state-directed development policy where a meritocratic bureaucracy plays an effective role. Singapore's highly rational bureaucracy is firm but not rigid and has moved from a problemsolving mode to a more "work smart", goal-directed mode. In 1995 Singapore began to prepare for a more corporate management style bureaucracy titled PS21, to meet the challenges of the 21st century (Goh, 1997). Such forwardlooking plans stood in good stead for future crisis handling. Singapore's strong foundation in health and biomedical science also played a critical role in innovation ranging from mask production to the application of Artificial intelligence (EDB, 2O2O). Singapore's primary healthcare settings provided a robust defence against Covid-19. "The Public Health Preparedness Clinic (PHPC) scheme, which consolidates the primary care clinic response to public health emergencies, was activated early in the outbreak. CoviD-19 testing capabilities were expanded to all government polyclinics" (Tan, et al., 2020:773).

Thomas Bellows attributes Singapore's remarkable success to its geographical location and its efficient and effective government (Bellows, 2009). Singapore state can mold society through effective policy instruments. Singapore was able to create active citizens through the institution of national service, a compulsory military or police service for two years for all male Singaporeans, and through the education system (Han, 2000). Singapore mobilized around 
3,0oo Social Distancing Ambassadors (SDA), who were recruited to enforce masking and social distancing rules.

Taiwan's success is remarkable despite being the nearest neighbor of China it achieved a low transmission of the disease and kept the death toll to a minimum without imposing any lockdown measure. Taiwan with a population of 23.8 million had 7 deaths (as of December 7 ) and 693 cases. The American state of Florida with a comparable population of 21.5 million (slightly less) suffered 17,60o deaths and 897,000 infections as of late November 2020 (Jennings and Hjelmgaard, 2020).

Taiwan's handling of the pandemic is regarded as one of the world's most successful containment outcomes. Collective intelligence - or "crowdsourcing" where everyone gets a say - is the ultimate form of inclusion. It is at the heart of everything she does in her role as digital minister. She strives to make sure that all voices are heard when devising public policy. Inclusiveness is crucial to innovation, Tang believes. "Innovation can become contagious," she said, and through diversity and inclusiveness, new technology becomes more accessible to people, so the public benefits. The combination of its open society and strong technology sector was crucial.

The government under President Tsai Ing-wen has led the country united by a common goal to fight the disease. Machine tool manufacturers answered a call from the government and put aside their rivalry to form a national team responsible for increasing Taiwan's daily output of masks tenfold to 20 million (Chen, J., 2020). Under the tireless leadership of the Central Epidemic Command Center, front-line medical professionals have made sacrifices and the public has put up with inconveniences while following restrictions imposed by the government (Chen, A., 2020).

To understand Taiwan's success it would be necessary to recount Taiwan's remarkable economic growth amidst challenges. After challenging times following the end of World War II, Taiwan adopted free-market capitalism since the mid-196os, based on privatizing the economy, a skilled labor force, astute planning, and engaging full throttle in global trade, Taiwan's economy took off and its fast-paced growth led many to use the term "miracle" to describe Taiwan's economic growth. Rapid social and political change, producing a large middle class, consumerism, Westernization, democratization followed economic growth (Copper, 2019). Taiwan thus became part of the Asian Tigers.

The key feature of the export-led growth model of the Tiger economies was their ability to shift the economic priorities depending on the demands of the 
market, moving from textile to auto parts, to computer peripherals in the case of Taiwan, financial services of Hong Kong and MNC-led growth of Singapore. After the Asian financial crisis in 1997-98, Singapore moved from MNC reliant growth model to a Government-Linked Company (GLC) model (Rodan, 2001) in which the role of the state was seminal. The state's ability to create a disciplined and pliant labor force was also a precondition. The ability to mobilize the labor force was a sideshow of the state's ability to mobilize its citizens for military service due to security concerns as in Korea and Taiwan and to some extent in Singapore, but not in Hong Kong. The thrust for economic development and the embrace of globalization helped build state capacity in planning and then executing and implementing those plans with a great deal of efficiency. The rise of the soft authoritarian state and panopticon surveillance was a trade-off that was accepted by people.

Politically, the Tiger economies have been divergent and the divergence has grown over the years. Hong Kong has seen a great deal of political activism with the population divided between pro and anti-mainland China camps, a divison rooted in the commitment to democracy and autonomy. Taiwan's democracy has been an arena of open contestation via elections between the Kuomintang (KMT) with a relatively more cooperative stance vis-à-vis mainland China and the Democratic Progressive Party (DPP), presently in power, that takes a more autonomous, and thus anti mainland China stance. The political activism often bordering on turmoil has affected state capacity in Taiwan. While in the case of Singapore, democracy has remained both procedural and peaceful. The differences in the political environment affected the state capacity in combating the COVID-19 pandemic.

\section{Transparency and Information Sharing}

Singapore showed a great deal of transparency, one of the main features of good governance, from the very onset of the pandemic. Not only, it shared information using all the available means, it mobilized public through various campaigns. Government publicity carried on the front page of Singapore's largest daily newspaper urge readers with even mild symptoms to see a doctor and refrain from going to school or work. To make quarantine less onerous, the government offers self-employed people $\$ 100$ Singapore dollars $(\$ 73)$ per day, while employers are prohibited from detracting quarantine days from staffers' annual leave (Barron, 2020). Singapore's excellent public health system made COVID-19 testing accessible to all. Singapore experienced a sharp increase in 
COVID-19 infections in April 2020 and safe distancing measures were considerably intensified to break the trend of increasing local transmission.

In Taiwan, early, widely broadcast communication about evolving infection information and policy updates delivered consistent messages, transparently that helped educate the population about self-protection and appropriate behavior (Lin, 2020). The free press and other media outlets in Hong Kong shared news about the pathogen openly.

\section{Trust and Social Mobilization}

Trust in any society is a variable and not a fixed social asset. In Taiwan, as control of China tightened limiting political openness, and exacted compliance from the local political authorities, trust in the government declined.

Although state role is considered seminal, in the case of Hong Kong not only the state, civil society and social mobilization of the society played a critical role in the fight against the pandemic (Wan, et al. 2020). Social capital (Putnam 200o) played a role in the mobilizing of Hong Kong citizens. Not only, it helped to cope with the stress of the pandemic (Lau, 2020), it also assisted the government in implementing various measures effectively as social capital determined citizens' response and compliance with regulations and guidelines (Ravat and $\mathrm{Wu}, 2020$ ). The experience of fighting SARS as early as 2003 equipped Hong Kong people with adequate knowledge of virus prevention, efforts to control COVID-19 also benefited from social capital developed during the prolonged social protest since 2019. People belonging to the pro-democracy camp took the initiative to deliver facemasks and advocate hygiene measures in Hong Kong, demonstrating strong community mobilization. This led to the emergence of bonding and bridging social capital (but not linking social capital) in local society, based substantially on similarity in political orientation (Lau, 202O). Studies elsewhere have shown that social capital both help bond and bridge (Pitas and Ehmer, 2020). The government's delayed provision of facemasks, which were not officially distributed until as late as 17 February 2020 (Home Affairs Bureau, 2020), led Hong Kong people (many of whom belonged to the opposition camp) to import facemasks and distribute them free of charge to underprivileged Hong Kong citizens, such as low-income families, ethnic minorities and older adults, regardless of their political orientation. As the demand for masks massively increased, other opposition camp members and organizations embarked on the local production and distribution of facemasks to help Hong Kong citizens avoid being price-gouged. 
Accordingly, bridging social capital was created via the intensive emergence of bonding social capital within the opposition camp. The distribution of facemasks has served as an important resource supporting the fight against coronavirus amongst Hong Kong people, raising community awareness, and mobilizing community adoption of hygiene standards.

In Taiwan, in addressing the threat of community spread of the virus, in addition to epidemic-prevention measures, community mobilization, citizen participation, and community partnerships played a key role (Lo, et al., 2020). A similar pattern in Singapore and Hong Kong was clearly evident too. Social mobilization and community awareness helped create a supportive mutual care system that played a role in tackling the crisis. In Singapore, the Ministry of Culture, Community and Youth developed a SGUnited portal by which the Government rallied Singaporeans and linked volunteers with resources to generate a whole-of-nation approach towards containing the effects of the crisis, which expanded the approach from the whole of government to the whole-ofnation (Low, 2020).

\section{State Intervention in Economy and Society}

Hong Kong was already mired in a recession when the pandemic hit thanks to the US-China trade war and months of political unrest last year. The new partial lockdown compounded economic misery. The Hong Kong authorities issued a one-time payment of nearly USD 650 to any citizen who tested positive for coronavirus, in a new measure taken to incentivize the population to be tested (Noticias Financieras, 2020, 22 November). Hong Kong government bailed out the city's flagship carrier Cathay Pacific Airways Ltd., providing it with the bulk of a $\$ 5$ billion funding package that might also give the government a minority stake in the 73-year-old company (Chiu and Yang, 2020).

According to the IMF, the Hong Kong economy contracted by 5.5 and 0.1 percent in Q1 and Q2, respectively. Hong Kong's economy fell into recession in the second quarter of 2020 and GDP was estimated to contract by $9 \%$ yearon-year, the authorities admitted, as drastic new rules of social estrangement came into force. The semi-autonomous region had already recorded a record contraction of $9.1 \%$ in the first quarter of the year. Even before the outbreak of the pandemic Hong Kong's GDP had fallen in the third and fourth quarters of 2019 as a result of the political situation and the consequences of the Sino-American trade war. An estimated $\mathrm{HK} \$ 311.5$ billion (or about 11 percent of GDP) of fiscal measures have been announced and are being implemented. (IMF, 2O2O). 
The authorities have announced several packages of fiscal support measures (February 18, March 26, April 6, April 21, May 26, August 17) amounting to about $\$ \$ 100$ billion. Support to households includes a cash payout to all Singaporeans (higher for families with children under 20) and additional payments for lower-income individuals and the unemployed. Support to businesses includes wage subsidies (extended through March 2021, with levels of support depending on the sector), support to cover rental costs, and enhancement of financing schemes, and additional support for the self-employed and industries most directly affected (aviation, tourism, construction, transportation, arts, and culture). The authorities have increased their contingencies funds for unforeseen expenditure needs and also set aside loan capital of $S \$ 20$ billion to help businesses and individuals facing cash flow challenges with loan obligations and insurance premium payments. Other economic resilience measures include support to R\&D investment, a national stockpile of health supplies, and a program on food resilience (IMF, 2020).

Singapore was able to change its strategy quickly moving to a more inclusive strategy as its state has evolved into an agile and smart state. An active and efficient state and a public health system played a crucial role in all the three Tiger economies proving that state efficiency rather than adherence to the neoliberal dogma can be a tool not only in guiding socio-economic development but also in crisis response.

\section{Embracing Science and Scientific Rationality}

State efficiency played a key role in fighting CoviD-19. The smart state was not only transparent and efficacious, it also developed a mindset of pragmatism and held science in high esteem. Science and technology received the special attention of the state. State invested in the promotion of science and technology. Singapore state not only became a model of transparency it also showed its unflinching support for the development of cutting-edge science.

On the science front, researchers of Hong Kong Baptist University (H KBU) developed a CoviD-19 alert system that will send a message to users through a mobile app if they and an infected person have visited the same place within a time period that gives rise to risks of exposure. And yet the system would not violate an individual's privacy by not collecting user's personal information. The system will not collect users' personal information and location data, thereby protecting individuals' privacy while alerting them on disease transmission risks associated with confirmed infection cases (BioSpectrum, 2020). 
In Taiwan, "Artificial intelligence technology has been employed to provide information on disease conditions and prevention and to implement a name-based system for purchasing face masks. An 'epidemic-prevention name list' was established using cloud data provided by the Health Insurance Department and National Immigration Agency. In this system, patients' travel histories can be immediately obtained using their health insurance cards. The National Health Command Center rapidly compiles epidemic information and feedback from communities" (Lo, et al. 2020).

Scientific rationality dominates the governance of the Asian tigers which accounted for their past success in economic management, such principles of economic management propel them to be at the cutting-edge of science and technology. The reliance on science and technology was uncompromised. The Asian Tigers are highly globalized, well-tuned to the global scientific networks when dealing with both routine governance issues as well as managing crises.

\section{Constraints of Geopolitics}

The vaccine debacle was mired in national politics as the government in power of the ruling party Democratic Progressive Party (DPP) is professedly antiPRC President Tsai is reluctant to take vaccine from PRC despite its positive overtures for which opposition party кмт has been very critical. On May 27 2021, Taiwan's Health Minister Chen Shih-chung disclosed that "BioNTech SE asked Taiwan to remove the words "my country" from a draft version of a news release that would have announced a vaccine deal" (Hsiao, et al., 2021). Talks with Germany's BioNTech had begun on Aug. 20 2020, but discussions ended in January 2021 over the wording of a news release, said Chen.

BioNTech distributes its products in China, Taiwan, Hong Kong and Macau through its distributor Fosun based in Shanghai, China. Fosun claimed that it wanted to provide vaccine to Taiwan, while Taiwan claimed that it was in direct negotiations with BioNTech. Taiwan has received only around 700,000 vaccine doses to date, all from AstraZeneca, and those are rapidly running out as it steps up vaccinations amid a spike in domestic infections. (The Straits Times, 2021). Taiwan accused China of meddling in the affairs, which China denied. China, in turn, wanted to play the good Samaritan by offering to help with not only vaccines but also medical personnel and expertise.

The political context of Hong Kong was marred by growing tension and division between the pro and anti-Chinese constituents. The yearning for democratic rights and the apprehension of losing their freedom was the immediate political context. The opposition groups were protesting since March 2020 
when China imposed a national-security law on the city, which constricted a long-running anti-government movement that challenged Beijing's authority. The political mobilization and confrontations continued as the pandemic unfolded. For example, Carrie Lam the chief executive of Hong Kong Special Administrative Region (SAR) was initially hesitant to close the border with China for obviously political reasons and was persuaded to do so only when 9, ooo hospital workers, comprising 3000 doctors, threatened to strike (Perrett, 2020). Even before the pandemic, Hong Kong was in the middle of political turmoil over China's tightening of grip on Hong Kong (Asia News Monitor, 12 June 2020).

The cancellation of the annual Tiananmen Square vigil on the ground that it would be a "major threat to public health" in the middle of the coviD-19 pandemic was viewed by the critics as evidence of China's tightening of the control of Hong Kong. When Chief Executive Carrie Lam decided to postpone legislative elections for a year, citing a recent surge in coronavirus cases. But the critics saw the decision as part of a continuing political crackdown. However, prominent pro-Beijing politicians had called for the vote to be postponed citing public health risks (Asia News Monitor, 2020, 3 August). In early September 2020 when China sent a team of experts to assist, pro-democracy groups in Hong Kong protested (BBC, 04 Sep 2020). The opposition political groups in Hong Kong were suspicious of testing conducted by the Chinese who came at the request of the Hong Kong government to assist. The proposed testing of 5 million people in Hong Kong was viewed with suspicion as the opposition leaders called for a boycott (Liu and Woodhouse, 2020).

The spread of virus in Taiwan in May 2021 posed a major threat to the global supply of integrated chips as Taiwan Semiconductor Manufacturing Company (TSMC) accounts for $80 \%$ of global production (Sankaran, 2021; Crawford et al., 2021). Taiwan's vaccine shortage impacting production of chips was linked to political circumstances of the region with grave economic concern for the world. The global interest in the vaccine shortage of Taiwan was not prompted by humanitarian concern as much as it was a politico-economic imperative.

\section{Concluding Remarks}

By comparing the relative success in the response to the CoviD-19 crisis and stalemate in vaccination we underscore that the theoretical focus on the state as an autonomous agent and its efficacy maybe misplaced unless it is contextualized in the global dynamics that influence the role of the state. In the case of Hong Kong, it is the changing political circumstances with growing 
domination of the mainland China impacted the political environment but not the state efficacy, while for Taiwan the political entanglements and wrangling with mainland China had a limiting impact on state capacity. Yet against all odds, Taiwan contained the community spread of the virus, in addition to epidemic-prevention measures, through community mobilization, citizen participation, and community partnerships. Collective intelligence, "crowd sourcing" strategies in Taiwan gave the country one of the best containment outcome in the world. In Hong Kong, political divisions did not stand in the way of collective mobilization. Oppostion parties swung into action, imported and distributed face masks among the people leveraging on the democratic space available in Hong Kong. Singapore's state was able to pursue its course more autonomously uneumbered by the influences of supra-political entities resulting in a more efficacious handling of the crisis. The limitations of the statist theory by the dynamics of globalization are thus clearly evident. Singapore's response graduated from all-government to all-state's response showing an exceptional ability of social mobilization.

While institutional memories stood in good stead in fighting and containing the pandemic, but when it came to vaccination, such institutional memories were not of much assistance. Insitutional memories turned out to be of limited value as the virus remained elusive and unpredictable.

Results of early success could not be sustained as the pandemic continued to ravage. The initial praise Singapore received melted as a large number of cases of infection among migrant workers came to light. Singapore's 300,000 migrant workers live in dormitories in shared accommodation where according to a local charity organization, HOME it was difficult to keep safe distance. Foreign workers who lived in dormitories accounted for nearly $90 \%$ of all the people who have tested positive for CoviD-19 in Singapore (The Economist, 2021 b). As of October 2020, Singapore had 57,980 confirmed cases of covid19 and 28 deaths (Tan et al., 2020). By the end of October 2021, the case loads were 184,419 with 349 deaths (Table 1). Despite the quick early response, as the pandemic entered the following year the initial success melted and the Singapore government settled for a living with the pathogen strategy having downgraded the pandemic to the status of an endemic. Although this is consistent with Singapore's commitment to pragmatism, there seem to be concerns and fear among the residents of Singapore as of mid-October 2021 (Cortez, et al., 2021). Only the future can judge the efficacy of this strategy. In the strategy of living with the virus on the strength of $81 \%$ vaccination rate compared to Hong Kong's 54\% as of mid October, 2021 (Correz, et al., 2021), Singapore has departed from Hong Kong's and for that matter China and Australia's zero tolerance policy of the virus. 
Paraphrasing Marx, it can be concluded that the states in the Tiger economies in the globalized world, however autonomous, may choose to adopt and execute their policies voluntarily but not under the circumstances chosen by themselves which remain under the grip of the dynamics of the forces of globalization with additional input from an unpredictable pathogen.

\section{References}

Abu Baker, Jalelah (2020) "Singapore Forms Wuhan Virus Ministerial Taskforce, Imported Case "inevitable", Gan Kim Yong" https://www.channelnewsasia.com/ singapore/wuhan-virus-singapore-ministerial-task-force-inevitable-786226.

Asia New Monitor (2020, August 3) "Hong Kong Postpones Elections By a Year, Citing Coronavirus" (Bangkok) August 3 .

Asia New Monitor (2020, September 8) "Hundreds Arrested in Hong Kong Protests to Commemorate Postponed Elections" (Bangkok) September 8.

Barron, Laigenee (2020) "What we can learn from Singapore, Taiwan and Hong Kong about handling coronavirus" Time, March 13.

в ВС Monitoring (2020) в вС Monitoring Asia Pacific; London [London]29 Apr 2020. в ВС Monitoring (2020) China sends another Covid-19 testing team to Hong Kong. в вс Monitoring Asia Pacific; London [London] о4 Sep 2020.

Bellows, Thomas J. (2009) "Meritocracy and the Singapore Political System", Asian Journal of Political Science, 17 (1) pp. 24-44.

BioSpectrum (2020) "Hong Kong launches Covid-19 alert system" Mumbai (Sep 1, 2020).

Brands, H (2020, March 17). Coronavirus is China's chance to weaken the liberal order. https://www.bloomberg.com/opinion/articles/2020-03-17/coronavirus-is -making-china-s-model-look-better-and-better.

CDC (2021) Centre for Disease Control, Government of Taiwan https://www.cdc.gov .tw/En/Bulletin/Detail/y7Nvv5uStwIV2iQngcT9ug?typeid=158.

Chan, Minnie (2021) “Will mainland Chinese Covid-19 vaccine offer overcome Taiwan's skepticism?" South China Morning Post. May 30.

Chen, Angela (2020) "Inclusiveness seen as key to Taiwan's success in containing COvid-19" Microsoft News. November 19. https://news.microsoft.com/apac/2020/ 11/19/inclusiveness-seen-as-key-to-taiwans-success-in-containing-of-Covid-19/.

Chen, Jacintha I-Pe, Yap, JCH, Hsu, LY, Teo, YY, (2020) "COVID-19 and Singapore: From Early Response to Circuit Breaker", Annals of the Academy of Medicine Singapore, August, 49 (8) $561-572$.

Chen, Jay (2020) "Taiwan's Covid-19 responses win applause, friendship from around the world" Business Wire, July 3. https:/www.businesswire.com/news/ 
home/20200703005042/en/Taiwan's-COVID-19-response-win-applause-friendship -from-around-the-world.

Chiu, Joanne and Jing Yang (2020) "Cathay Pacific to get Bailout Led by Hong Kong Government. Dow Jones Institutional News, New York, I June 2020.

Chung, Lawrence (2021) "Coronavirus: Taiwan Relaxes rules for vaccine imports as deaths mount", South China Morning Post, May 28.

Copper, J Franklin (2019) Taiwan: Nation State or Province? Taylor and Francis (E-Book). Cortez, Michelle Fay, Faris Mokhtar, and Low De Wei (2021) "Singapore Confronts the Division and Fear That Come From Living with the Covid", Bloomberg. https://www.bloomberg.com/news/articles/2021-10-14/singapore-confronts -division-and-fear-bred-by-living-with-covid.

Crawford, A, Wu, D, and Marlow, I (2021) "World's Supply of Chips is in Danger Unless Taiwan Gets Vaccine", Bloomberg, May 27. https://www.bloombergquint. com/global-economics/world-s-supply-of-chips-is-in-danger-unless-taiwan-gets -vaccines.

Delanty, Gerard (ed) (2021) Pandemic, Politics, and Society: Critical Perspectives on the Covid-19 Crisis. Berlin / Boston: De Gruyter.

The Economist (2021a) "Post-Covid syndrome: The sting in the tail" May 1 pp. 65-67.

The Economist (2021b) "Covid-19 in Singapore: Fever Cabins", June 19 p. 49.

E D B (2020) "Innovation in Crisis: Singapore Flexes Biomed Chops Against Covid-19" https://www.edb.gov.sg/en/news-and-events/insights/innovation/innovation-in-a -crisis-singapore-flexes-biomed-chops-against-Covid-19.html.

Fouskas V, and Gokay B (2020) CovID-19 and the bankruptcy of neoliberalism in the context of global shift. Open Democracy, May 5, 2020 (Date accessed: December 10, 2020). https://www.opendemocracy.net/en/can-europe-make-it/Covid-19-and-ban kruptcy-neoliberalism-context-global-shift.

Han, Christine (2000) "National Education and 'Active Citizenship' Implementation for Citizenship and Citizenship Education in Singapore", Asia Pacific Journal of Education. 20 (1) 63-72.

Home Affairs Bureau, (2020), "Workgroup on public participation together, we fight the virus", https://www.hab.gov.hk/en/policy_responsibilities/District_Community _and_Public_Relations/working_group.htm (accessed 2 August 202O).

Hong Kong Government (2O2O) January 3. https://www.news.gov.hk/eng/2O2O/o1/2O2 o0103/20200103_193832_o67.html?type =category\&name $=$ Covidig\&tl=t_ $\quad$ (accessed 2 August 2020).

Hsiao, Sherry (2O21) "CEEC reports 401 local COVID-19 cases, 13 deaths", Taipei Times, May 28. P.1.

Hsiao, Sherry, Peng Wan-hsin and Jake Chung (2021) "BioNTech asked to cut "country": Chen", Taipei Times, May 28, 2021. 
Hsieh, Vivian Chia-Rong (2020) "Putting Resiliency of a health system to the test: COVID-19 in Taiwan" Journal of Formosa Medical Association. April, 119 (4): 884-885. Published online 2020 Mar 21. DOI: 10.1016/j.jfma.2020.03.002.

IMF (2020) Policy Responses to Covid-19: Policy Tracker https://www.imf.org/en/ Topics/imf-and-Covid19/Policy-Responses-to-Covid-19\#B.

Jasanoff, Shelia, et al. (2021) Comparative Covid Response: Crisis, Knowledge, Politics. Harvard Kennedy School, January 12.

Jennings, Ralph and Hjelmgaard, Kim (2020) "No Lockdowns, no downturn: Taiwan attracts skilled expats with (mostly) COVID-19 free life" USA Today, November 24.

Kalimuddin, Shirin, Antonio Bertoletti and Ooi Eng Eong (2021) "ScienceTalk: Vaccination is key to Singapore's fight against Covid-19”. The Straits Times May 23 https://www.straitstimes.com/singapore/health/sciencetalk-vaccination-is-key -to-singapores-fight-against-Covid-19.

Koh, Gillian (1997) Bureaucratic rationality in an evolving developmental state: Challenges to governance in Singapore, Asian Journal of Political Science, 5:2, 114-141, DOI: 10.108 o/o2185379708434108.

Lau, Pui Yan Flora (2020), "Fighting COVID-19: social capital and community mobilisation in Hong Kong", International Journal of Sociology and Social Policy, Vol. 40 No. 9/10, pp. 1059-1067. https://www.doi.org/10.1108/IJSSP-o8-2020-0377.

Lee, I-chia (2021) “Level 3 - alert extended to June 14" Taipei Times, May 26.

Lin, Chia-nan (2021) "Moderna vaccines touch down in Taoyuan", Taipei Times, May 29. Lin, Cheryl, Mullen, J, Braund, WE, Tu, P, and Auerbach, J (2020) "Reopening safely Lessons from Taiwan's CoVID-19 response”,Journal of Global Health.10 (2) December: o20318 Published online 2020 Jul 28. DoI: 10.7189/jogh.10.020318.

Liu, Nicolle; Woodhouse, Alice (2020) Hong Kong activists distrust Covid-19 mass testing: Privacy fears", Financial Times, London (UK) [London (UK)]о2 Sep 2020: 6.

Lo, Anglea, Huang, JJ, Chen, CC, Chou, FHC, and Shieh, V (2020) "From Biological safety to social safety: How Taiwan's community centered prevention program controlled the CoviD-19 outbreak", Journal of Global Health 10 (2), December. 020303 Published online 2020 Jul 21. DoI: 10.7189/jogh.10.0203०3.

Low, James (2O2O) “COVID-19 Crisis Management: An Early Look" Civil Service College, https://www.csc.gov.sg/articles/covid-19-crisis-management-an-early-look.

Maçães, B (2020, March 10). Coronavirus and the clash of civilizations. National Review. https://www.nationalreview.com/2020/03/coronavirus-and-the-clash-of -civilizations/.

Nederveen Pieterse, Jan, H Lim, and H Khondker (eds) (2021) Covid-19 and Governance. New York: Routledge.

Noticias Financieras (2020) "Hong Kong government handed over $\$ 65$ o to those who test positive for coronavirus". 
Perrett, Connor (2020) "9,ooo Hong Kong hospital workers are threatening to strike amid coronavirus outbreak if the government doesn't close its border with mainland China", Business Insider (New York), February 1 ,

Pitas, N, and Ehmer, C (2020), "Social capital in the response to COVID-19", American Journal of Health Promotion, May 2020. DOI: 10.1177/o890117120924531.

Putnam, R (2000), Bowling Alone: The Collapse and Revival of American Community, Simon \& Schuster, New York, NY.

Rawat, S, and $\mathrm{Wu}, \mathrm{A}(2 \mathrm{O2O})$, "Why social capital is essential in the fight against covid-19", Policy Forum, Asia and the Pacific Policy Society, 23 June 2020, available at: https://www.policyforum.net/why-social-capital-is-essential-in-the-fight -against-Covid-19/(accessed 10 December, 2020).

Reuters. (2021) https://graphics.reuters.com/world-coronavirus-tracker-and-maps/ (accessed on October 28, 2021).

Rodan, Gary (2001) "Singapore: Globalisation and the Politics of Economic Restructuring" in Gary Rodan, Kevin Hewison, and Richard Robison (eds) The Political Economy of South-East Asia. New York: Oxford University Press.

Root, Hilton (1996) Small Countries, Big Lessons: Governance and the Rise of East Asia. Hong Kong: Oxford University Press.

Sankaran, V (2021) "Global computer chip shortage may worsen unless Taiwan gets vaccine", Independent, May 24. https://www.independent.co.uk/news/long_reads/ science-and-technology/taiwan-Covid-chip-shortage-b1852659.html.

Siu, Phila, Victor Ting and Elizabeth Cheung (2020) "Coronavirus: Clusters alert at major Hong Kong department store amid "worsening” fourth wave, as city records 78 new cases" South China Morning Post, December 7.

Tan, Trevor HY, Matthias Paul Han Sim Toh, Shawn Vasoo, David Chien Boon Lye, Brenda Sze Peng Ang, Yee Sin Leo, Vernon Jian Ming Lee, Ser Hon Puah, Asok Kurup (2020). "Coronavirus Disease 2019 (COVID-19): The Singapore Experience. A Review of the First Eight Months" Ann Acad Med Singap. Oct;49(10):764-778. https:// pubmed.ncbi.nlm.nih.gov/33283840/.

Teo, Joyce (2021) "Singapore still ranks high in Covid-19 vaccination pace despite supply constraints. The Straits Times, https:/www.straitstimes.com/singapore/health/ singapore-still-ranks-high-in-vaccination-pace-despite-supply-constraints.

Ting, Victor and Ho-him, Chan, (2021) "Coronavirus: health experts suggest selling Hong Kong's unused vaccines or pausing fresh supplies as expiry date looms", South China Morning Post May 26. https://www.scmp.com/news/hong-kong/ health-environment/article/3134835/coronavirus-health-experts-suggest-selling-or.

The Straits Times (2021) “China's Fosun says it's willing to provide BioNTech vaccines to Taiwan" https://www.straitstimes.com/asia/east-asia/chinas-fosun-says-willing -to-provide-biontech-vaccines-to-taiwan. 
Wang CJ, Ng CY, Brook RH. Response to CoviD-19 in Taiwan: Big Data Analytics, New Technology, and Proactive Testing. JAMA. 2020;323(14):1341-1342. DOI:10.1001/ jama.2020.3151.

Wan, Kin-Man, et al. (2O20) "Fighting COviD-19 in Hong Kong: The Effects of Community and Social Mobilization" World Development 134 (105055).

World Bank (1993) The East Asian Miracle. New York: Oxford University Press.

Yen, Muh-Yong, Yung-Feng Yen, Shey-Ying Chen, Ting-I Lee, Kuan-Han Huang, Ta-Chien Chan, Tsung-Hua Tung, Le-Yin Hsu, Tai-Yuan Chiu, Po-Ren Hsueh, and Chwan-Chuen King (2021) "Learning from the past: Taiwan's responses to CoviD-19 versus SARs.” International Journal of Infectious Diseases. Sep; 110: 469-478. 